\title{
Potentiation of Low Dose Ketamine Effects by Naltrexone: Potential Implications for the Pharmacotherapy of Alcoholism
}

\author{
John H Krysta|*,1,2,3, Steven Madonick 1,2,3,4, Edward Perry',2,3, Ralitza Gueorguieva ${ }^{3,5}$, Laura Brush ${ }^{1,2}$, \\ Yola Wray ${ }^{1,2}$, Aysenil Belger ${ }^{1,2,6}$ and Deepak Cyril D'Souza ${ }^{1,2,3}$ \\ 'Department of Psychiatry, Yale University School of Medicine, New Haven, CT, USA; ${ }^{2}$ Alcohol Research Center (I I 6-A), VA Connecticut \\ Healthcare System, West Haven, CT, USA; ${ }^{3}$ Clinical Neuroscience Research Unit, Abraham Ribicoff Research Facilities, Connecticut Mental \\ Health Center, New Haven, CT, USA; ${ }^{4}$ Institute of Living, Hartford Hospital, Hartford, CT, USA; ${ }^{5}$ Section of Biostatistics, School of Epidemiology \\ and Public Health, Yale University School of Medicine, New Haven, CT, USA; ${ }^{6}$ Department of Psychiatry, University of North Carolina Medical \\ School, Chapel Hill, NC, USA
}

\begin{abstract}
The interplay of opiate and NMDA glutamate receptors may contribute to psychosis, cognitive function, alcoholism, and substance dependence. Ketamine and ethanol block the NMDA glutamate receptor. The purpose of this randomized double-blind, placebocontrolled human laboratory study was to evaluate whether the interactive effects of drugs acting at opiate and NMDA glutamate receptors might partially explain the efficacy of naltrexone for the treatment of alcoholism, that is, whether naltrexone $25 \mathrm{mg}$ pretreatment would modulate ketamine effects in healthy human subjects. Two groups of healthy subjects were studied. An initial group $(n=31)$ received a perception-altering subanesthetic dose of ketamine (bolus of $0.23 \mathrm{mg} / \mathrm{kg}$ over I min followed by a 60 -min infusion of $0.58 \mathrm{mg} / \mathrm{kg}$ or saline bolus and infusion). A second group $(n=24)$ completed the same testing procedures, but received a subperceptual ketamine dose (bolus $0.08 \mathrm{I} \mathrm{mg/kg} \mathrm{over} 10 \mathrm{~min}$ followed by an infusion of $0.4 \mathrm{mg} / \mathrm{kg} / \mathrm{h}$ ). Ketamine produced positive symptoms, negative symptoms, emotional discomfort, and cognitive effects as measured by the Positive and Negative Syndrome Scale (PANSS) in a doserelated fashion. The lower ketamine dose produced subjective effects similar to two standard ethanol drinks, whereas the higher ketamine dose produced effects similar to five standard drinks. Although naltrexone produced no significant behavioral effects, it significantly magnified the increase in the total PANSS score produced by the lower subperceptual dose of ketamine, but not the higher perception-altering dose of ketamine. These data suggest that the interplay of opiate receptor antagonism and NMDA receptor antagonism may be relevant to the protective effects of naltrexone on alcohol consumption via potentiation of dysphoric effects associated with the NMDA receptor antagonist effects of ethanol. However, these data suggest that at levels of NMDA receptor antagonism associated with heavy drinking, this protective effect of naltrexone on drinking is no longer present. Neuropsychopharmacology (2006) 31, 1793- 1800. doi: I 0. I038/sj.npp. I 300994; published online 4 January 2006
\end{abstract}

Keywords: NMDA receptor; psychosis; alcoholism; opiate receptor; naltrexone

\section{INTRODUCTION}

$N$-methyl-D-aspartate (NMDA) glutamate receptors and $\mu$ opiate receptors may play opposing roles in the regulation of reward, mood, and cognition. However, little is known about psychopharmacologic aspects of the interplay of drugs acting at these receptors in humans. Binding studies describe colocalization of NMDA and $\mu$-opiate receptors in the nucleus accumbens (Gracy et al, 1997) and nucleus

\footnotetext{
*Correspondence: Dr JH Krystal, Alcohol Research Center (I|6-A), Yale University School of Medicine, VA Connecticut Healthcare System, 950 Campbell Avenue, Park Street, West Haven CT 065 I6, USA, Tel: + 203937 4790, Fax: + 203937 3468;

E-mail: john.krystal@yale.edu

Received I June 2005; revised 5 August 2005; accepted 7 September 2005

Online publication: 28 October 2005 at http://www.acnp.org/citations/ Npp I02805050360/default.pdf
}

tractus solitarius (Huang et al, 2000). In the raphe nucleus, nucleus accumbens, and prefrontal cortex, the excitatory effects of NMDA receptor stimulation are opposed by the inhibitory effects of $\mu$-opiate receptor stimulation. Also, NMDA receptor antagonist effects are reduced by opiate receptor antagonists (Jolas and Aghajanian, 1997; Marek and Aghajanian, 1998; Martin et al, 1997). In contrast, in Xenopus oocytes, there is evidence that opiates administered at very high doses may inhibit NMDA receptor function at a site within the cation channel (Yamakura et al, 1999).

The interplay of NMDA glutamate receptors and $\mu$-opiate receptors may be particularly important to the field of addiction research. With respect to opiate addiction, NMDA receptor antagonists block the development of opiate dependence (Sepulveda et al, 2002; Trujillo and Akil, 1995). A growing body of alcoholism research has emphasized the interplay of opiate antagonists and ethanol, 
itself an NMDA receptor antagonist (Krystal et al, 2003b). Opiate receptor antagonists reduce the rewarding effects of ethanol(O’Malley et al, 1996; Volpicelli et al, 1995) and the consumption of ethanol (O'Malley et al, 1992; Volpicelli et al, 1992). Further, the combination of NMDA and opiate receptor antagonists may have greater beneficial effects for recovering alcohol-dependent patients than either drug administered by itself (Kiefer et al, 2003).

The NMDA receptor antagonist, ketamine, is the principal drug used to probe the role of NMDA glutamate receptors in human cognition and behavior (Krystal et al, 1999). However, the interpretation of ketamine effects generated by the racemic formulation that is most commonly used in psychopharmacology research may be complicated by the modest affinity that the R-isomer of ketamine possesses for the $\mu$-opiate receptor (Hustveit et al, 1995; Smith et al, 1980). Other preclinical studies suggest that opiate receptormediated effects are not relevant to the cognitive and behavioral effects of ketamine (Byrd et al, 1987; Fidecka, 1987; France and Woods, 1989; Fratta et al, 1980; Shannon and Holtzman, 1977), but this finding has yet to be demonstrated in humans outside of the context of anesthesia (Stella et al, 1984).

The purpose of the current study was to evaluate glutamate-opiate receptor interactions in humans by studying the impact of pretreatment with naltrexone, $25 \mathrm{mg}$, p.o., upon the dose-related cognitive and behavioral effects of ketamine in a double-blind, randomized, double placebocontrolled design.

\section{METHODS}

This study was approved by the Yale Department of Psychiatry Research Committee, New Haven, CT, the Yale University Human Investigations Committee, New Haven, CT, and the Human Subjects Subcommittee of the VA Connecticut Healthcare System, West Haven, CT. The study was conducted at the Neurobiological Studies Unit (VA Connecticut Healthcare System, West Haven, CT). Healthy subjects were recruited by public advertisement and compensated for their research participation. After giving written informed consent, subjects underwent a rigorous evaluation that determined that they (1) were medically healthy by history, physical examination, and laboratory testing, (2) did not meet a DSM-IV axis I diagnosis by structured diagnostic interview (Spitzer et al, 1990), and (3) did not give evidence of substance abuse or dependence by history, physical examination, or urine toxicology (performed at screening and on each test day). Subjects were instructed to refrain from caffeine intake for 2 weeks prior to testing and throughout the study.

\section{Subjects}

A total of 55 healthy human subjects completed testing: 31 completed the four test days involving a higher perceptionaltering ketamine dose and 24 subjects completed the four test days involving the subperceptual ketamine dose. The mean age of the sample was $28.1 \pm 7.6$ year (SD). In all, 26 subjects were female $(47.3 \%)$ and 29 subjects were male $(52.7 \%)$. The majority of subjects were nonsmokers $(n=42$,
$76.4 \%$ ), four subjects smoked (7.3\%); one subject had smoked in the past $(1.8 \%)$, and smoking data were not available for eight subjects (14.5\%).

\section{Procedures}

This study was conducted in two phases. In the initial phase, the higher dose of ketamine (i.v. bolus of $0.23 \mathrm{mg} / \mathrm{kg}$ over $1 \mathrm{~min}$ followed by $0.58 \mathrm{mg} / \mathrm{kg} / \mathrm{h}$ ) was tested. Subjects completed four test days in randomized order under double-blind conditions: placebo naltrexone and saline (placebo ketamine), naltrexone $25 \mathrm{mg}$, p.o. and saline, placebo naltrexone and ketamine, and naltrexone and ketamine. The drugs were administered in a fixed order with naltrexone $25 \mathrm{mg}$ or a matched placebo given $90 \mathrm{~min}$ prior to the initiation of ketamine or saline infusion. In the second phase, identical procedures were followed, except that a lower ketamine dose (bolus $0.081 \mathrm{mg} / \mathrm{kg}$ over $10 \mathrm{~min}$ followed by an infusion of $0.4 \mathrm{mg} / \mathrm{kg} / \mathrm{h}$ ) was administered.

A timeline for test days is presented in Figure 1. Subjects fasted after midnight prior to test days. They appeared for testing at approximately 0830 hours on test days. This study employed cognitive and clinical assessments that we have used previously to study ketamine effects in healthy subjects and alcohol dependent patients (Krystal et al, 1994, 1998, 2003a). The Positive and Negative Syndrome Scale (PANSS (Kay et al, 1989)) was employed to assess several dimensions of behavior. In this report, empirically derived factors are reported excluding those items that could not be assessed during the test sessions (Bell et al, 1994): positive symptom factor (delusions, unusual thoughts, somatic concern, grandiosity, suspiciousness, and hallucinations), negative symptom factor (emotional withdrawal, blunted affect, poor rapport, disturbance of volition, preoccupation, and motor retardation), cognitive factor (difficulty in abstract thinking, stereotyped thinking, cognitive disorganization, lack of judgement and insight, poor attention, tension, mannerisms, and posturing), hostility (excitement, hostility, impulse control, and uncooperativeness), emotional discomfort (depression, anxiety, and guilt). In addition, subjects completed visual analog scales (VAS) measuring high, drowsiness, nervousness, and the number of standard alcohol drinks that would be anticipated to produce the subjective effects experienced at a given timepoint (the 'number of drinks' scale) (Krystal et al, 1998). The Biphasic Alcohol Effects scale (BAES) contains seven items measuring stimulatory effects associated with ethanol and seven items that assess sedative effects associated with ethanol (Martin et al, 1993). The Hopkins Verbal Learning Test (HVLT) (Brandt, 1991) also was administered on each test day.

\section{Data Analysis}

Data were checked for normality before analysis. Since most outcome variables exhibited floor effects and positive skewness, we used the nonparametric approach for repeated measures data (Brunner et al, 2002). In the overall model for BAES ascending, BAES descending, PANSS total score, the five PANSS subscales (positive, negative, cognitive, emotional, and hostility), the four VAS subscales (high, tired, drowsy, and nervous), and the similarity to alcohol 

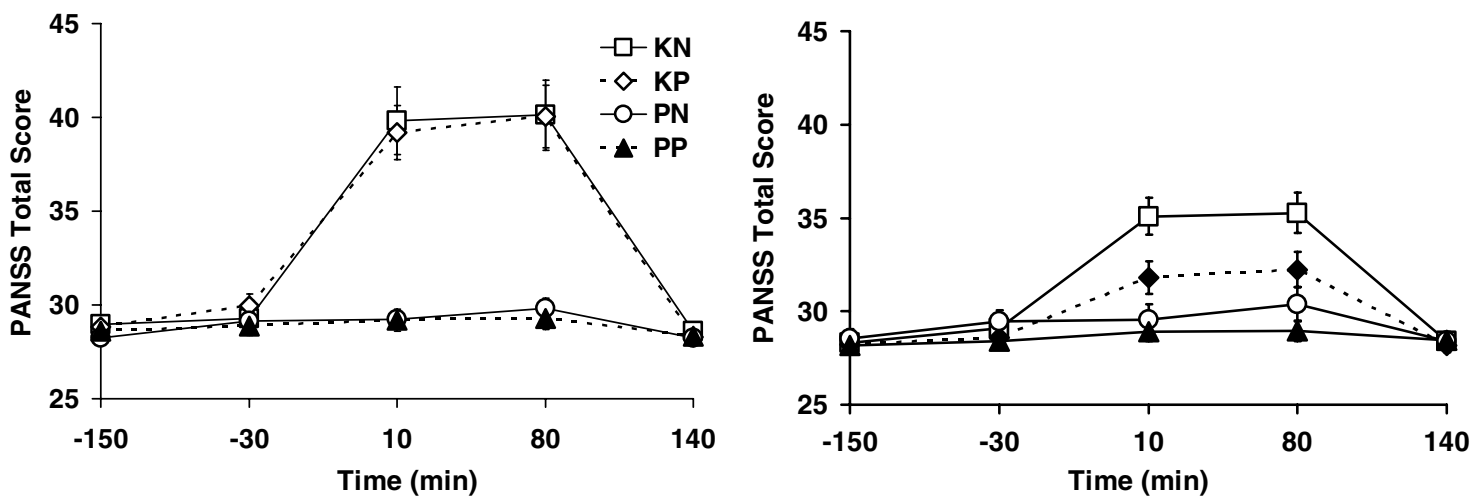

Figure I This figure depicts the PANSS total score results. Data are presented as mean values \pm SEM. Results of the data analyses are presented in Table 2. The left figure presents the results of the higher perception-altering dose of ketamine and the right figure shows the results from the lower subperceptual dose of ketamine. $\mathrm{K}=$ ketamine, $\mathrm{N}=$ naltrexone, $\mathrm{P}=$ placebo.

Table I The Timing of Procedures for Test Days

\begin{tabular}{|c|c|}
\hline Time (min) & Procedure \\
\hline$-150:$ & $\begin{array}{l}\text { IV placed. ETOH Battery (Biphasic Alcohol Effects Scale; } \\
\text { Visual Analog Scales for mood, similarity to ethanol, side } \\
\text { effects; Number of Drinks Scale) }\end{array}$ \\
\hline-120 & $\begin{array}{l}\text { Positive and Negative Symptoms Scale (PANSS), Clinician- } \\
\text { Administered Dissociative States Scale (CADSS), }\end{array}$ \\
\hline-90 & Administration of naltrexone $25 \mathrm{mg}$ or matched placebo, p.o. \\
\hline $0:$ & Infusion of ketamine or saline placebo \\
\hline 5: & ETOH Battery \\
\hline \multirow[t]{2}{*}{ 15: } & Continuous performance test of distractibility \\
\hline & Hopkins Verbal Learning Test \\
\hline 30: & ETOH battery, PANSS, CADSS, vital signs \\
\hline 60: & ETOH battery; ketamine infusion terminated \\
\hline 70: & PANSS, CADSS \\
\hline 100: & $\begin{array}{l}\text { ETOH battery, PANSS, CADSS, Ribicoff Abstinence Rating } \\
\text { Scale }\end{array}$ \\
\hline 180: & PANSS, CADSS, Test Day Debriefing and Discharge \\
\hline
\end{tabular}

effect, ketamine dose (low dose $v s$ high dose) was used as a between-subject factor, whereas ketamine (Active, Placebo), naltrexone (Active, Placebo), and time (study timepoints, see Table 1) were used as within-subject factors. Subject was used as the clustering factor. The analysis of HVLT data was similar, except instead of time there was an effect of repetition for immediate recall to assess learning effects. The analysis was performed via the use of PROC MIXED on the ranked data with appropriate adjustment for $p$-values. If significant interactions involving ketamine dose were observed, separate follow-up analyses within the high-dose ketamine group and the low-dose ketamine group were also performed. Bonferroni adjustment was applied within but not across hypotheses.

\section{RESULTS}

\section{PANSS}

The analyses of PANSS data are summarized in Table 2. The initial analysis focused on the PANSS total score. This analysis, depicted in Figure 1, revealed the naltrexone potentiated the effects of the lower, but not the higher, ketamine dose. As presented in Table 2, the ketamine by time interaction, naltrexone by time interaction, and the interaction of ketamine dose, ketamine, naltrexone, and time were significant. For the lower ketamine dose, both the ketamine by time interactive effect (ATS $=1.81, \mathrm{df}=6.63$, $p=0.002)$ and the naltrexone by time interactive effect (ATS $=2.55, \mathrm{df}=4.66, p=0.005$ ) were significant. For the higher ketamine dose, the ketamine by time interaction effect was highly significant (ATS $=2.11, \mathrm{df}=89.50$, $p<0.0001$ ), but the naltrexone and naltrexone by time interaction effects were not significant. Neither the ketamine by time interaction nor the ketamine by naltrexone by time interaction was significant for either dose.

There were significant dose-related ketamine effects on four of the five PANSS factors (positive symptoms (Figure 2), negative symptoms (Figure 3), cognition, and hositility), and naltrexone had no significant effects by itself. The interaction of ketamine dose, ketamine, naltrexone, and time for the emotional discomfort factor data failed to make the Bonferroni-corrected threshold for significance for this outcome $(p<0.01$; Figure 4$)$. As the interaction was significant at the uncorrected significance level of 0.05 , post hoc testing was performed. These tests revealed that the 'discomforting' effects of the higher dose of ketamine were not significantly influenced by naltrexone pretreatment, whereas naltrexone pretreatment modestly, but significantly, increased the effects of low-dose ketamine on this outcome measure (ketamine by naltrexone by time interaction: $\mathrm{ATS}=2.9, \mathrm{df}=2.7, p=0.04)$.

\section{VAS and Number of Drinks Scale}

The results of the analyses of VAS are summarized in Table 1. Ketamine produced significant dose-related euphoria, drowsiness, and sedation. It also had effects that were deemed significantly similar to those of ethanol in a dose-related fashion. Naltrexone had no significant effects on any of the VAS. None of the interactions between ketamine dose, ketamine, naltrexone, and time reached the significance threshold for this study. However, the four-way interaction for the 'high' VAS was significant at an uncorrected significance level of 0.05 , so post hoc tests were 
Table 2 Summary of Results ${ }^{\mathrm{a}}$

\begin{tabular}{|c|c|c|c|c|c|}
\hline Outcome & $\begin{array}{l}\text { Ketamine by time } \\
\text { interaction }\end{array}$ & $\begin{array}{l}\text { Ketamine dose by ketamine } \\
\text { by time }{ }^{c}\end{array}$ & Naltrexone by time ${ }^{d}$ & $\begin{array}{l}\text { Naltrexone by ketamine } \\
\text { by time }\end{array}$ & $\begin{array}{l}\text { Naltrexone by ketamine } \\
\text { dose by ketamine by } \\
\text { time }\end{array}$ \\
\hline \multicolumn{6}{|l|}{ PANSS } \\
\hline PANSS total score & $\begin{array}{l}\text { ATS }=2.09, \mathrm{df}=84.05, \\
p<0.000 \mathrm{I}\end{array}$ & ATS $=2.09, \mathrm{df}=0.38, p=0.7$ & $\begin{array}{l}\text { ATS }=2.6 I, d f=2.72, \\
p=0.05 I\end{array}$ & $\begin{array}{l}\text { ATS }=2.15, d f=2.21 \\
p=0.11\end{array}$ & $\begin{array}{l}\text { ATS }=2.15, \mathrm{df}=3.22 \\
p=0.036\end{array}$ \\
\hline PANSS positive symptom factor & $\begin{array}{l}\text { ATS }=57.8, \mathrm{df}=\mathrm{I.7} I \\
p<0.000 \mathrm{I}\end{array}$ & $\mathrm{ATS}=0.23, \mathrm{df}=1.71, p=0.76$ & $\begin{array}{l}\text { ATS }=0.55, d f=2.91 \\
p=0.64\end{array}$ & $\begin{array}{l}\text { ATS }=1.44, d f=2.58 \\
p=0.23\end{array}$ & $\begin{array}{l}\text { ATS }=0.46, d f=2.58 \\
p=0.69\end{array}$ \\
\hline PANSS negative symptom factor & $\begin{array}{l}\text { ATS }=34.53, \mathrm{df}=\mathrm{I} .92, \\
\mathrm{p}<0.000 \mathrm{I}\end{array}$ & $\begin{array}{l}\text { ATS }=3.57, d f=1.92 \\
p=0.03\end{array}$ & $\begin{array}{l}\text { ATS }=3.76, d f=2.73 \\
p=0.01\end{array}$ & $\mathrm{ATS}=1.26, \mathrm{df}=2.38 p=0.28$ & $\mathrm{ATS}=2.47, \mathrm{df}=2.38 p=0.07$ \\
\hline PANSS cognitive symptom factor & $\begin{array}{l}\text { ATS }=74.74, \mathrm{df}=\mathrm{I} .85 \\
p<0.000 \mathrm{I}\end{array}$ & $\mathrm{ATS}=1.15, \mathrm{df}=1.85, p=0.31$ & ATS $=1.48, d f=2.19 p=0.23$ & $\mathrm{ATS}=1.16, \mathrm{df}=2.51 p=0.32$ & ATS $=1.64, d f=2.51 p=0.19$ \\
\hline $\begin{array}{l}\text { PANSS emotional discomfort } \\
\text { factor }\end{array}$ & $\begin{array}{l}\text { ATS }=3.94, \mathrm{df}=2.50 \\
p=0.0125\end{array}$ & ATS $=1.25, d f=2.50, p=0.29$ & $\mathrm{ATS}=0.76, \mathrm{df}=2.52 p=0.50$ & $\mathrm{ATS}=2.22, \mathrm{df}=2.82 p=0.09$ & $\begin{array}{l}\text { ATS }=2.86, d f=2.82 \\
p=0.04\end{array}$ \\
\hline PANSS hostility factor & $\begin{array}{l}\text { ATS }=7.35, \mathrm{df}=2.43 \\
p=0.0002\end{array}$ & ATS $=0.62, d f=2.43, p=0.57$ & ATS $=1.04, d f=2.05 p=0.35$ & ATS $=2.51, \mathrm{df}=1.85 p=0.09$ & ATS $=0.09, \mathrm{df}=1.85 p=0.90$ \\
\hline \multicolumn{6}{|l|}{ VAS } \\
\hline VAS high & $\begin{array}{l}\text { ATS }=187.80, \mathrm{df}=1.40, \\
p<0.0001\end{array}$ & ATS $=2.77, d f=1.40, p=0.08$ & ATS $=1.40, d f=2.02 p=0.25$ & $\mathrm{ATS}=1.36, \mathrm{df}=2.14 p=0.26$ & $\begin{array}{l}\text { ATS }=3.09, d f=2.14 \\
p=0.04\end{array}$ \\
\hline VAS drowsy & $\begin{array}{l}\text { ATS }=5.04, \mathrm{df}=2.34 \\
p=0.004\end{array}$ & $\begin{array}{l}\text { ATS }=5.24, d f=2.34 \\
p=0.003\end{array}$ & ATS $=0.4 \mathrm{I}, \mathrm{df}=2.94 p=0.74$ & $\mathrm{ATS}=1.33, \mathrm{df}=2.81 \mathrm{p}=0.26$ & $\mathrm{ATS}=0.08, \mathrm{df}=2.8 \mathrm{I} p=0.96$ \\
\hline VAS nervous & $\begin{array}{l}\text { ATS }=3.39, \mathrm{df}=2.23 \\
p=0.03\end{array}$ & $\mathrm{ATS}=0.15, \mathrm{df}=2.23, p=0.88$ & ATS $=2.99, \mathrm{df}=2.76 p=0.03$ & ATS $=0.58, d f=2.53 p=0.60$ & $\mathrm{ATS}=0.76, \mathrm{df}=2.53 p=0.50$ \\
\hline \multicolumn{6}{|l|}{ BAES } \\
\hline BAES stimulant subscale & $\begin{array}{l}\text { ATS }=17.02, \mathrm{df}=1.72 \\
p<0.000 \mathrm{I}\end{array}$ & $\begin{array}{l}\text { ATS }=3.64, \mathrm{df}=\mathrm{I} .75 \\
p=0.03\end{array}$ & $\mathrm{ATS}=2.26, \mathrm{df}=2.74 p=0.09$ & $\mathrm{ATS}=0.5 \mathrm{I}, \mathrm{df}=2.29 p=0.62$ & $\mathrm{ATS}=1.99, \mathrm{df}=2.27 p=0.13$ \\
\hline BAES sedative subscale & $\begin{array}{l}\text { ATS }=36.57, \mathrm{df}=2.33 \\
p<0.000 \mathrm{I}\end{array}$ & $\mathrm{ATS}=2.67, \mathrm{df}=2.38, p=0.06$ & $\mathrm{ATS}=0.43, \mathrm{df}=2.66 p=0.7 \mathrm{I}$ & $\mathrm{ATS}=0.3 \mathrm{l}, \mathrm{df}=2.90 p=0.8 \mathrm{I}$ & ATS $=0.46, d f=2.90 p=0.7 \mathrm{I}$ \\
\hline \multicolumn{6}{|l|}{ HVLT } \\
\hline Immediate recall & $\begin{array}{l}\text { ATS }=6.31, \mathrm{df}=1.91 \\
p=0.002\end{array}$ & ATS $=2.69, \mathrm{df}=1.91, p=0.07$ & $\begin{array}{l}\text { ATS }=0.45, d f=1.95 \\
p=0.63\end{array}$ & ATS $=0.2, d f=1.85, p=0.80$ & $\begin{array}{l}\text { ATS }=0.36, d f=1.85 \\
p=0.68\end{array}$ \\
\hline Delayed recall ${ }^{8}$ & ATS $=2.64, d f=1, p=0.11$ & ATS $=0.38, d f=1, p=0.54$ & $\mathrm{ATS}=1.73, \mathrm{df}=1, p=0.19$ & ATS $=0.61, d f=1, p=0.43$ & ATS $=0.43, d f=1, p=0.51$ \\
\hline
\end{tabular}

The threshold for statistical significance adopted for this study was $p<0.01$. Findings with $p<0.05$ are bolded in the table.

betamine by time interaction effects reflect ketamine effects over the test day relative to placebo, irrespective of the ketamine dose

Ketamine dose by ketamine by time interaction effects indicate the dependency of the ketamine by time interaction upon ketamine dose

'Naltrexone by time interaction effects show the time-dependent effects of naltrexone.

eNaltrexone by ketamine by time interaction effects characterize the impact of naltrexone upon ketamine response over time irrespective of ketamine dose.

fNaltrexone by ketamine dose by ketamine by time interaction effects reflect whether naltrexone interacts with ketamine over time in a manner that is dependent on the dose of ketamine that is administered.

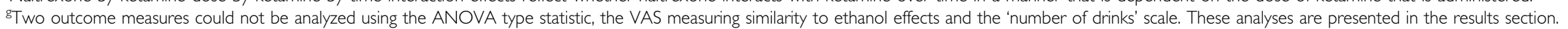



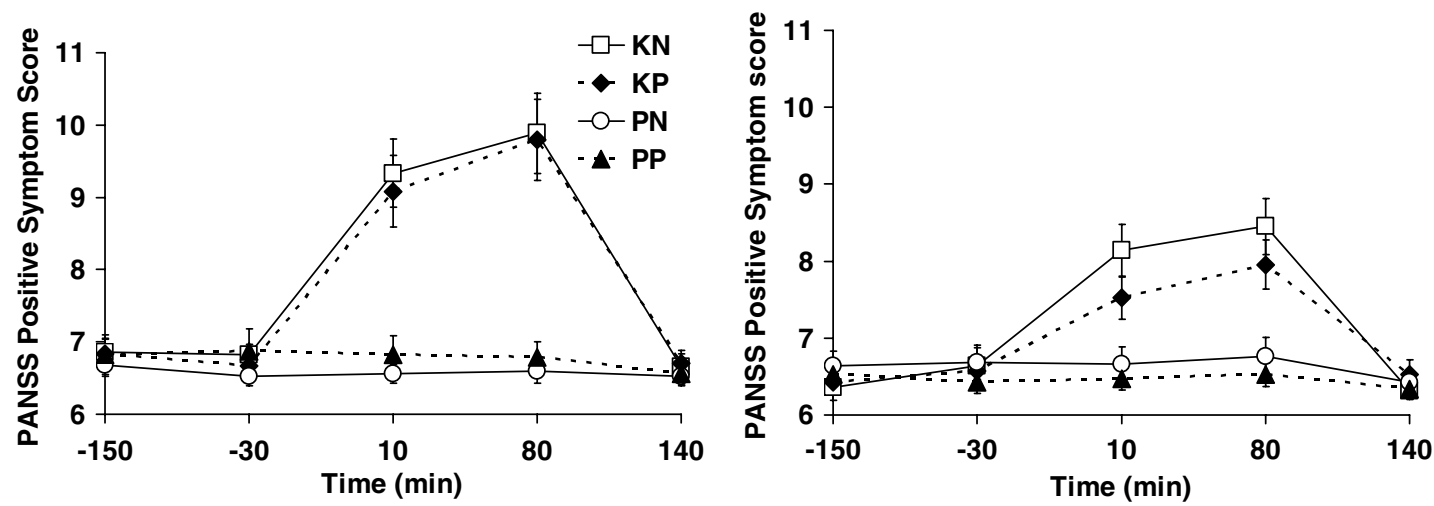

Figure 2 This figure depicts the PANSS positive symptom factor score results. Data are presented as mean values \pm SEM. Results of the data analyses are presented in Table 2. The left figure presents the results of the higher perception-altering dose of ketamine and the right figure shows the results from the lower subperceptual dose of ketamine. $\mathrm{K}=$ ketamine, $\mathrm{N}=$ naltrexone, $\mathrm{P}=$ placebo.
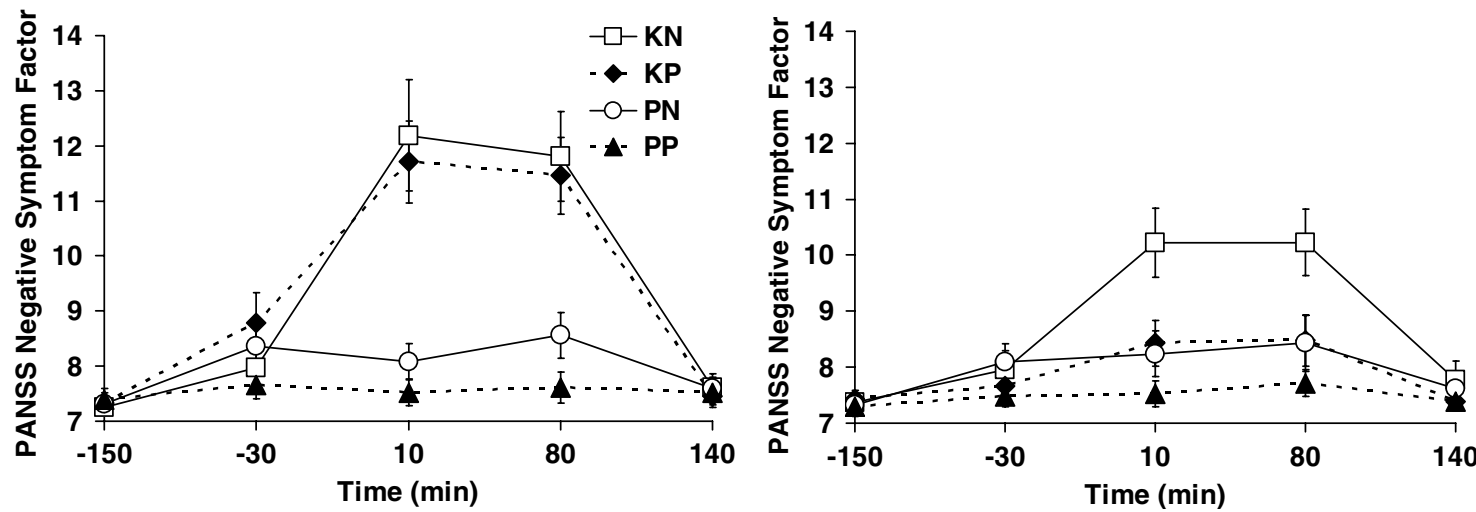

Figure 3 This figure depicts the PANSS negative symptom factor score results. Data are presented as mean values + SEM. Results of the data analyses are presented in Table 2. The left figure presents the results of the higher perception-altering dose of ketamine and the right figure shows the results from the lower sub-perceptual dose of ketamine. $\mathrm{K}=$ ketamine, $\mathrm{N}=$ naltrexone, $\mathrm{P}=$ placebo.
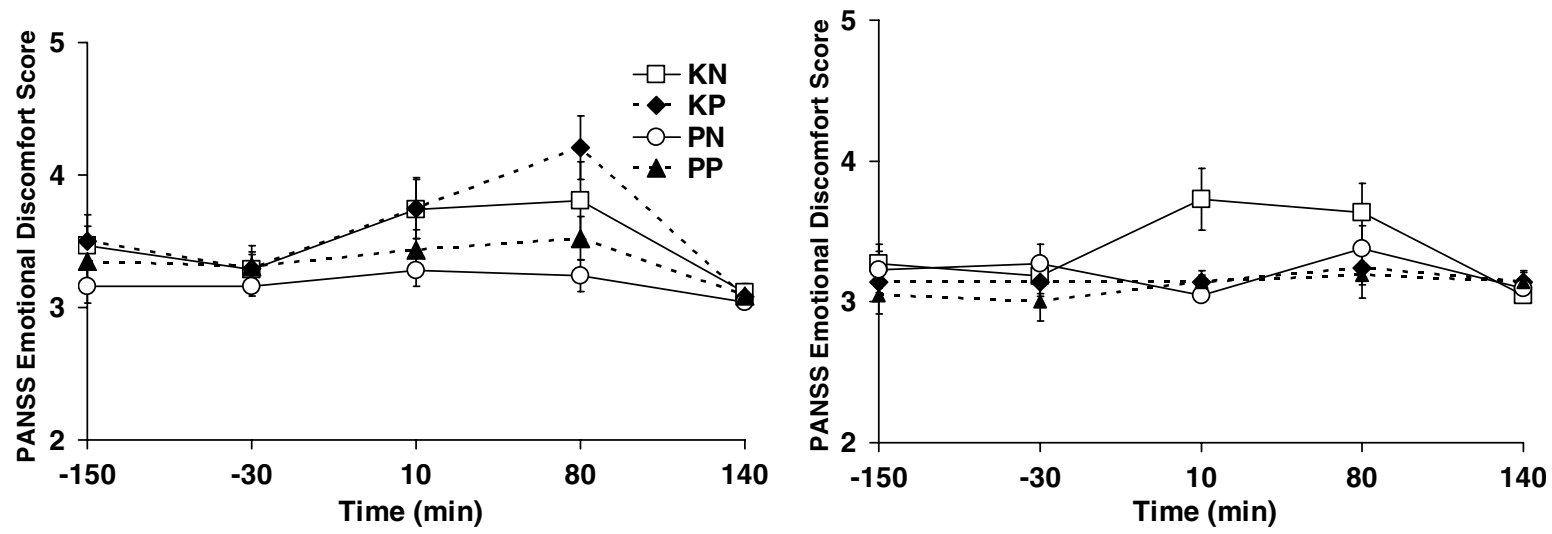

Figure 4 This figure presents the PANSS emotional discomfort factor score results. Data are presented as mean values \pm SEM. Results of the data analyses are presented in Table 2. The left figure presents the results of the higher perception-altering dose of ketamine and the right figure shows the results from the lower subperceptual dose of ketamine. $\mathrm{K}=$ ketamine, $\mathrm{N}=$ naltrexone, $\mathrm{P}=$ placebo.

performed (see Figure 5). This analysis revealed a modest, but significant, increase in the euphoric effects of the lower ketamine dose following naltrexone pretreatment (ketamine by naltrexone by time interaction: $\mathrm{ATS}=3.78, \mathrm{df}=2.09$, $p=0.02$.

The results for the Number of Drinks Scale, reflecting the number of ethanol drinks that would be anticipated to produce a subjective sense of intoxication comparable to the subjective state at the rating time, are presented in Figure 6. Whereas the ketamine by time interaction was significant $(\mathrm{ATS}=2.52, \mathrm{df}=86.32, p<0.0001)$, there was no significant main effect of naltrexone or significant ketamine dose by ketamine by naltrexone by time interaction. 

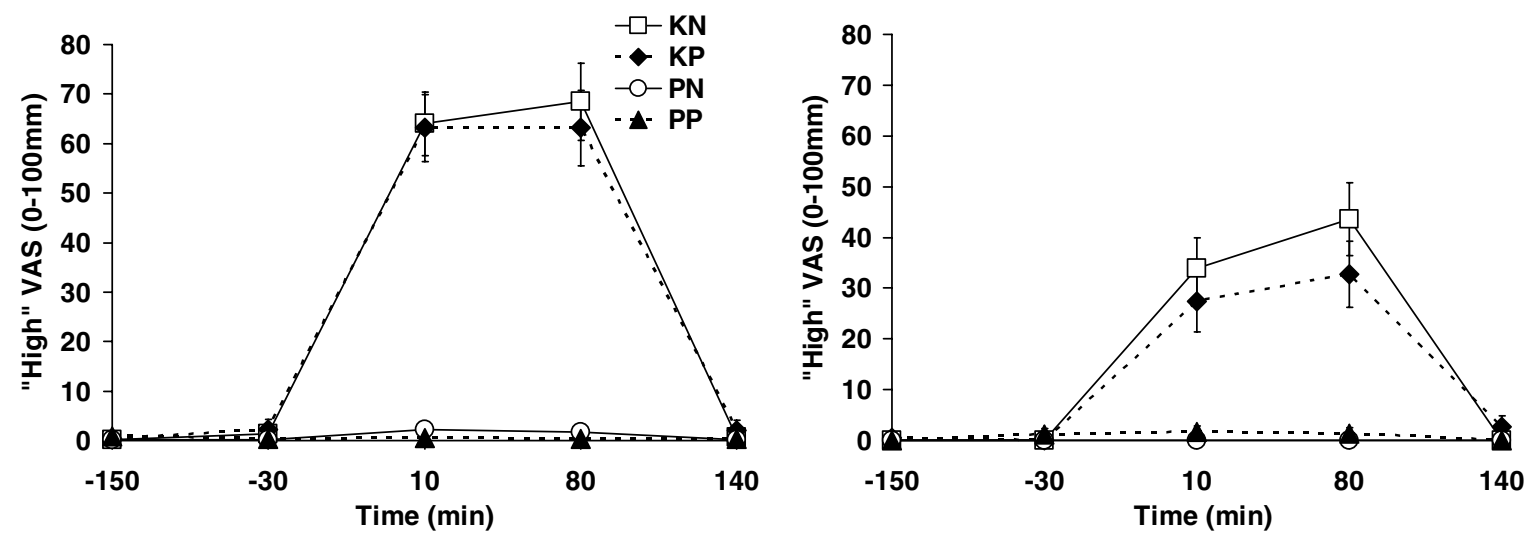

Figure 5 This figure presents the 'high' VAS (range 0-100 mm) results. Data are presented as mean values \pm SEM. Results of the data analyses are presented in Table 2. The left figure presents the results of the higher perception-altering dose of ketamine and the right figure shows the results from the lower subperceptual dose of ketamine. $\mathrm{K}=$ ketamine, $\mathrm{N}=$ naltrexone, $\mathrm{P}=$ placebo.
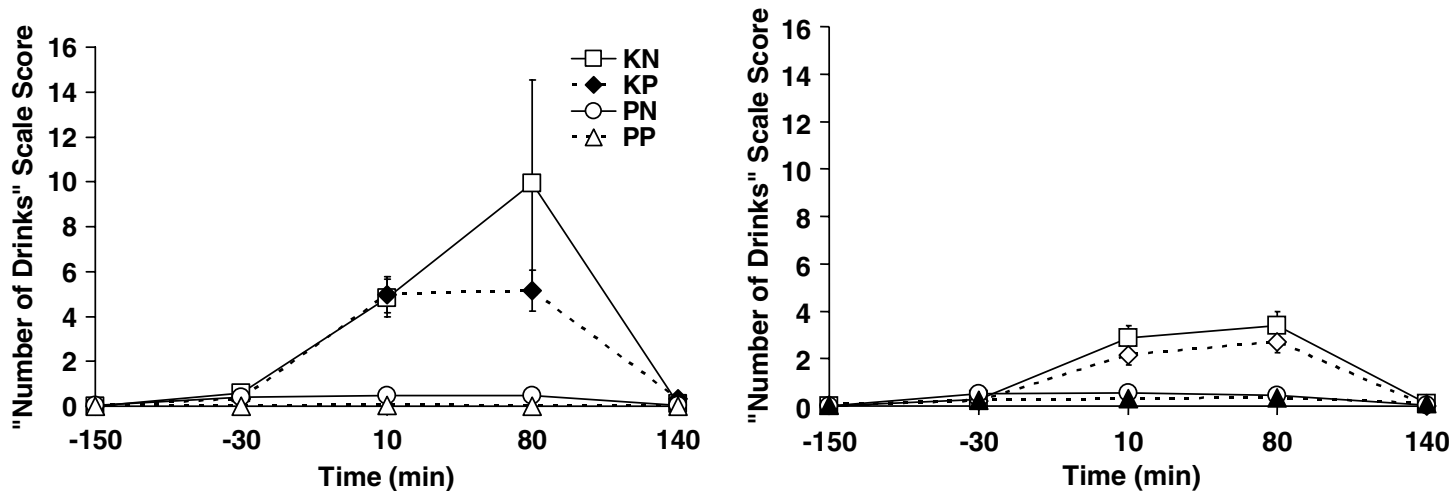

Figure 6 This figure presents the 'number of drinks scale' results. This scale measures the number of standard ethanol drinks needed to produce the current subjective state. Data are presented as mean values \pm SEM. Results of the data analyses are presented in Table 2 . The left figure presents the results of the higher perception-altering dose of ketamine and the right figure shows the results from the lower subperceptual dose of ketamine. $\mathrm{K}=$ ketamine, $\mathrm{N}=$ naltrexone, $\mathrm{P}=$ placebo.

\section{Biphasic Alcohol Effects Scale}

Ketamine produced significant stimulant and sedative effects as measured by the subscales of the BAES, but the effects of either ketamine dose were not significantly modulated by naltrexone pretreatment (Table 2).

\section{Hopkins Verbal Learning Test}

Ketamine significantly impaired immediate recall (Table 2). Naltrexone did not have a significant effect and it did not modify the ketamine effect on immediate recall. Controlling for immediate recall tested on the third trial, neither ketamine nor naltrexone impaired delayed recall.

\section{DISCUSSION}

The principal finding of this study was that pretreatment with naltrexone increased some effects of a subperceptual subanesthetic dose of ketamine, but this same dose of naltrexone did not alter the effects of a higher perceptionaltering subanesthetic dose of ketamine when administered to healthy human subjects. This pattern of interaction between naltrexone and ketamine was observed for the total
PANSS score. It was also present in secondary analyses of the emotional discomfort factor of the PANSS and the 'high' VAS. This study also found that opiate receptors, particularly the $\mu$-opiate receptor, do not contribute substantially to other cognitive and behavioral effects of ketamine in healthy human subjects. Also, there was no evidence that ketamine effects were antagonized by naltrexone pretreatment. Thus, this study does not provide evidence that any direct effects of either isomer of ketamine are mediated by stimulation of opiate receptors.

The ability of naltrexone pretreatment to increase the 'high' and emotional discomfort produced by low-dose ketamine may suggest a novel mechanism through which it plays a role in the treatment of alcohol dependence. As noted in the introduction, early studies suggested that naltrexone attenuated the euphoric effects of alcohol consumption (O'Malley et al, 1996; Volpicelli et al, 1995). However, a laboratory study from this period also suggested that naltrexone potentiated sedation and other effects of ethanol associated with descending blood ethanol levels (Swift $e t$ al, 1994). The current data raise the possibility that naltrexone modestly potentiates feelings of intoxication, both euphoria and emotional discomfort, associated with modest levels of NMDA receptor antagonism, as might be 
associated with low levels of ethanol intoxication (Krystal et al, 1998).

Naltrexone may potentiate a negative feedback signal on drinking that is both unclear and different than simply increasing the perceived number of alcohol drinks consumed, as this outcome measure was not significantly altered. The low dose ketamine was perceived as similar to 2-3 standard alcohol drinks regardless of naltrexone, whereas the higher ketamine dose was perceived as similar to approximately five standard alcohol drinks when administered by itself and approximately nine standard alcohol drinks when administered following naltrexone (see Figure 6). However, there was no significant interaction between ketamine, naltrexone, and time effects for either ketamine dose for the 'number of drinks' scale data.

The inability of naltrexone to modulate the cognitive and behavioral effects of the higher ketamine dose could signal a limitation on naltrexone's efficacy in treating alcohol dependence. Dosing issues may be very important to the interplay of NMDA receptor antagonists and drugs acting at opiate receptors. Two studies that reported synergy between opiate receptor agonist and NMDA receptor antagonist effects when both drugs were administered at low doses found no interactive drug effects (Young et al, 1992) or found the opposite pattern of interactive effects (Hance et al, 1989) when higher opiate doses were administered. The multicenter study of alcoholism conducted within the VA failed to find a significant naltrexone effect (Krystal et al, 2001) and its research patients drank more heavily at baseline and more rapidly progressed during treatment from their first drink of alcohol to heavy drinking than did the patients in early positive naltrexone trials (Anton et al, 1999; O’Malley et al, 1992; Volpicelli et al, 1992).

Future research may address limitations of the current study. First, the applicability of the findings of this study to alcoholism treatment may be limited by the relatively low dose of naltrexone employed. This study evaluated naltrexone $25 \mathrm{mg}$ due to concern that higher naltrexone doses might produce nausea and vomiting when administered with ketamine. However, clinical trials of naltrexone treatment for alcohol dependence study doses up to $100 \mathrm{mg}$. Naltrexone, at $25 \mathrm{mg}$, should have produced a nearly complete blockade of $\mu$-opiate receptors (Lee et al, 1988). But, it is possible that higher naltrexone doses would have produced greater effects via $\delta$ - or $\kappa$-opiate receptors, where it has nearly 16.7 -fold and 5.6-fold lower affinity, respectively (Ananthan et al, 1999). Second, this study was conducted in healthy human subjects without a family history of alcohol dependence. The presence of a family history of alcohol dependence has been shown to influence ketamine response and the interactive effects of naltrexone and ethanol in healthy human subjects (King et al, 1997; Petrakis et al, 2004). Different response patterns might have been observed in individuals with a family history of alcohol dependence. Third, this study sequentially evaluated the two ketamine doses in two separate subject groups, raising the possibility that ketamine dose and order effects were confounded in this study and reducing the statistical power for the comparisons across ketamine dose relative to the within subjects analyses.

Overall, the current data describe an interaction between NMDA glutamate receptors and opiate receptors. However, the interactive effects were not very prominent. Thus, the data may suggest that maintaining the tone of endogenous opiate systems is not critical for expressing the cognitive and behavioral effects of NMDA glutamate receptor antagonists.

\section{ACKNOWLEDGEMENTS}

This work was supported by the National Institute on Alcohol Abuse and Alcoholism via RO1 AA12308-01, KO5 AA 14906-01, and I-P50 AA-12870-04. It is also supported by the Department of Veterans Affairs via support for the Alcohol Research Center, Schizophrenia Biological Research Center, and National Center for PTSD. The authors thank Angelina Genovese, RN, and Elizabeth O'Donnell, RN, of the Biological Studies Unit of the VA Connecticut Healthcare System for their contributions to the success of this project. The authors also thank Ms Corie Palazollo for her expert assistance in the preparation of this manuscript.

\section{REFERENCES}

Ananthan S, Kezar HSI, Carter RL, Saini SK, Rice KC, Wells JL et al (1999). Synthesis, opioid receptor binding, and biological activities of naltrexone-derived pyrido- and pyrimidomorphinans. J Med Chem 42: 3527-3538.

Anton RF, Moak DH, Waid LR, Latham PK, Malcolm RJ, Dias JK (1999). Naltrexone and cognitive behavioral therapy for the treatment of outpatient alcoholics: results of a placebocontrolled trial. Am J Psychiatry 156: 1758-1764.

Bell MD, Lysaker PH, Beam-Goulet JL, Milstein RM, Lindenmayer JP (1994). Five-component model of schizophrenia: assessing the factorial invariance of the positive and negative syndrome scale. Psychiatry Res 52: 295-303.

Brandt J (1991). The Hopkins Verbal Learning Test: development of a new memory test with six equivalent forms. Clin Neuropsychol 5: 125-142.

Brunner E, Domhof S, Langer F (2002). Nonparametric Analysis of Longitudinal Data in Factorial Experiments. Wiley: New York.

Byrd LD, Standish LJ, Howell LL (1987). Behavioral effects of phencyclidine and ketamine alone and in combination with other drugs. Eur J Pharmacol 144: 331-341.

Fidecka S (1987). Opioid mechanisms of some behavioral effects of ketamine. Pol J Pharmacol Pharm 39: 353-360.

France CP, Woods JH (1989). Discriminative stimulus effects of naltrexone in morphine-treated rhesus monkeys. J Pharmacol Exp Therapeut 250: 937-943.

Fratta W, Casu M, Balestrieri A, Loviselli A, Biggio G, Gessa GL (1980). Failure of ketamine to interact with opiate receptors. Eur J Pharmacol 61: 389-391.

Gracy KN, Svingos AL, Pickel VM (1997). Dual ultrastructural localization of mu-opioid receptors and NMDA-type glutamate receptors in the shell of the rat nucleus accumbens. J Neurosci 17: 4839-4848.

Hance AJ, Winters WD, Quam DD, Benthuysen JL, Cadd GG (1989). Catalepsy induced by combinations of ketamine and morphine: potentiation, antagonism, tolerance and cross-tolerance in the rat. Neuropharmacology 28: 109-116.

Huang J, Wang H, Pickel VM (2000). Rostrocaudal variation in targeting of $\mathrm{N}$-methyl-D-aspartate and mu-opioid receptors in the rat medial nucleus of the solitary tract. J Comparat Neurol 421: 400-411.

Hustveit O, Maurset A, Oye I (1995). Interaction of the chiral forms of ketamine with opioid, phencyclidine, sigma and muscarinic receptors. Pharmacol Toxicol 77: 355-359. 
Jolas T, Aghajanian GK (1997). Opioids suppress spontaneous and NMDA-induced inhibitory postsynaptic currents in the dorsal raphe nucleus of the rat in vitro. Brain Res 755: 229-245.

Kay SR, Opler LA, Lindenmayer JP (1989). The Positive and Negative Syndrome Scale (PANSS): rationale and standardisation. Br J Psychiatry-Supplement 7: 59-67.

Kiefer F, Jahn H, Tarnaske T, Helwig H, Briken P, Holzbach R et al (2003). Comparing and combining naltrexone and acamprosate in relapse prevention of alcoholism: a double-blind, placebocontrolled study. Arch Gen Psychiatry 60: 92-99.

King AC, Volpicelli JR, Frazer A, O'Brien CP (1997). Effect of naltrexone on subjective alcohol response in subjects at high and low risk for future alcohol dependence. Psychopharmacology 129: $15-22$.

Krystal JH, Cramer JA, Kroll W, Kirk G, Rosenheck RA, Group VANCS (2001). Naltrexone in the treatment of alcohol dependence. $N$ Engl J Med 345: 1734-1739.

Krystal JH, D'Souza DC, Petrakis IL, Belger A, Berman R, Charney DS et al (1999). NMDA agonists and antagonists as probes of glutamatergic dysfunction and pharmacotherapies for neuropsychiatric disorders. Harvard Rev Psychiatry 7: 125-133.

Krystal JH, Karper LP, Seibyl JP, Freeman GK, Delaney R, Bremner JD et al (1994). Subanesthetic effects of the noncompetitive NMDA antagonist, ketamine, in humans psychotomimetic, perceptual, cognitive, and neuroendocrine responses. Arch Gen Psychiatry 51: 199-214.

Krystal JH, Petrakis IL, Limoncelli D, Webb E, Gueorgueva R, D'Souza DC et al (2003a). Altered NMDA glutamate receptor antagonist response in recovering ethanol dependent patients. Neuropsychopharmacology 28: 2020-2028.

Krystal JH, Petrakis IL, Mason G, D'Souza DC (2003b). NMDA glutamate receptors and alcoholism: reward, dependence, treatment, and vulnerability. Pharmcol Therapeut 99: 79-94.

Krystal JH, Petrakis IL, Webb E, Cooney NL, Karper LP, Namanworth S et al (1998). Dose-related ethanol-like effects of the NMDA antagonist, ketamine, in recently detoxified alcoholics. Arch Gen Psychiatry 55: 354-360.

Lee MC, Wagner Jr HN, Tanada S, Frost JJ, Bice AN, Dannals RF (1988). Duration of occupancy of opiate receptors by naltrexone. J Nucl Med 29: 1207-1211.

Marek GJ, Aghajanian GK (1998). 5-Hydroxytryptamine-induced excitatory postsynaptic currents in neocortical layer $\mathrm{V}$ pyramidal cells: suppression by mu-opiate receptor activation. Neuroscience 86: 485-497.

Martin CS, Earleywine M, Musty RE, Perrine MW, Swift RM (1993). Development and validation of the Biphasic Alcohol Effects Scale. Alcohol Clin Exp Res 17: 140-146.
Martin G, Nie Z, Siggins GR (1997). mu-Opioid receptors modulate NMDA receptor-mediated responses in nucleus accumbens neurons. J Neurosci 17: 11-22.

O'Malley SS, Jaffe AJ, Chang G, Schottenfeld RS, Meyer RE, Rounsaville B (1992). Naltrexone and coping skills therapy for alcohol dependence. A controlled study. Arch Gen Psychiatry 49: 881-887.

O'Malley SS, Jaffe AJ, Rode S, Rounsaville BJ (1996). Experience of a 'slip' among alcoholics treated with naltrexone or placebo. Am J Psychiatry 153: 281-283.

Petrakis IL, Limoncelli D, Guerguieva R, Jatlow P, Boutros NN, Trevisan L et al (2004). Altered NMDA glutamate receptor antagonist response in individuals with a family vulnerability to alcoholism. Am J Psychiatry 161: 1776-1782.

Sepulveda J, Ortega A, Zapata G, Contreras E (2002). Acamprosate decreases the induction of tolerance and physical dependence in morphine-treated mice. Eur J Pharmacol 445: 87-91.

Shannon HE, Holtzman SG (1977). Further evaluation of the discriminative effects of morphine in the rat. J Pharmacol Exp Therapeut 201: 55-66.

Smith DJ, Pekoe GM, Martin LL, Coalgate B (1980). The interaction of ketamine with the opiate receptor. Life Sci 26: 789-795.

Spitzer RL, Williams JBW, Gibbon M, First MB (1990). Structured Clinical Interview for DSM-III-R-Non-Patient Edition (SCID-NP, Version 1.0 with supplement for DSM-IV). American Psychiatric Press: Washington, DC.

Stella L, Crescenti A, Torri G (1984). Effect of naloxone on loss of consciousness induced by i.v. anesthetic agents in man. $\mathrm{Br} J$ Anesthes 56: 369-373.

Swift RM, Whelihan W, Kuznetsov O, Buongiorno G, Hsuing H (1994). Naltrexone-induced alterations in human ethanol intoxication. Am J Psychiatry 151: 1463-1467.

Trujillo KA, Akil H (1995). Excitatory amino acids and drugs of abuse: a role for $N$-methyl-D-aspartate receptors in drug tolerance, sensitization and physical dependence. Drug Alcohol Dependence 38: $139-154$.

Volpicelli JR, Alterman AI, Hayashida M, O’Brien CP (1992). Naltrexone in the treatment of alcohol dependence. Arch Gen Psychiatry 49: 876-880.

Volpicelli JR, Watson NT, King AC, Sherman CE, O'Brien CP (1995). Effect of naltrexone on alcohol 'high' in alcoholics. Am J Psychiatry 152: 613-615.

Yamakura T, Sakimura K, Shimoji K (1999). Direct inhibition of the $N$-methyl-D-aspartate receptor channel by high concentrations of opioids. Anesthesiology 91: 1053-1063.

Young AM, Masaki MA, Geula C (1992). Discriminative stimulus effects of morphine: effects of training dose on agonist and antagonist effects of mu opioids. J Pharmacol Exp Therapeut 261: 246-257. 